\title{
Inheritance Pattern of Growth and Wood Traits in Teak (Tectona grandis L.f.).
}

\author{
By C. NARAYANAN ${ }^{*}$, P. H. ChaWhaAN ${ }^{1)}$ and A. K. MANDAL ${ }^{2)}$
}

(Received $26^{\text {th }}$ November 2008)

\begin{abstract}
Inheritance pattern of wood traits, especially heart$\mathrm{wood} /$ sapwood percentage and specific gravity and interactions of wood traits with other growth traits were investigated in a 27-year-old half-sib progeny trial of teak. Wood traits showed highly significant variation for specific gravity, heartwood and sapwood percentage at family level. There was non-significant family vs. replication variation for these traits. Among the growth traits, there was significant variation for height and girth. Families and individual trees showed varying levels of heritability. Among the growth traits, height showed high heritability (individual tree heritability, $h^{2}{ }_{(i)}=34.3 \%$; family heritability, $\left.h^{2}(f)=34.1 \%\right)$ followed by girth $\left(h^{2}{ }_{(i)}=19.4 \% ; h^{2}(f)=31.4 \%\right)$. Among the wood traits, maximum heritability values were obtained for sapwood percentage $\left(h^{2}{ }_{(i)}=76.6 \% ; h^{2}{ }_{(f)}=70.7 \%\right)$ and heartwood percentage $\left(h_{(i)}^{2}=76.9 \% ; h^{2}(f)=69.7 \%\right)$. Specific gravity exhibited heritability values of 29.1 and $41.8 \%$, at individual tree and family level, respectively. Family heritability was higher than single-tree heritability for specific gravity; single-tree heritability exceeded family heritability for heartwood percentage. Specific gravity exhibited significant positive genotypic correlation with heartwood percentage suggesting that improvement in heartwood percentage would lead to a correlated improvement in specific gravity. Heartwood percentage showed significant positive correlation with growth traits viz., height and girth. Some of the families showed good GCA for growth and wood traits investigated. The good general combiners identified in the present study can be used for establishment of advanced generation seed orchards and breeding arboreta for improvement of teak for specific or combination of above traits.
\end{abstract}

Key words: Inheritance pattern, half-sib progeny trial, heritability, heartwood percentage, sapwood percentage, height, girth, specific gravity, general combining ability, genetic gain.

\section{Introduction}

Teak (Tectona grandis L.f.), a highly favored tropical tree widely grown for its highly durable and attractive wood, ranks third next only to Eucalyptus spp. and Acacia spp. in its plantation area. Teak constitutes about $8 \%$ of the plantations in countries with climatic regimes suitable for teak growth (PANDEY and BROwN, 2001). The estimated global production of tropical hardwood logs,

\footnotetext{
1) P. H. CHAWhaAn, Arid Forest Research Institute, Jodhpur, India.

$\left.{ }^{2}\right)$ A. K. MANDAL, Tropical Forest Research Institute, Jabalpur, India.

*) Corresponding author: Crop Improvement Group, Rubber Research Institute of India, India. Ph: +91-481-2353311, Fax: +91-481-2353327. E-Mail: cnarayanan@rubberboard.org.in
}

including teak, in 1998 was around 123 million $\mathrm{m}^{3}$ (IтTO, 1998). Yet, the demand for high quality wood is expected to continue to grow, despite gains made in engineered timber and other low cost substitutes (EARHART, 1999).

Being one of the most important timber-yielding tree species, intensive genetic improvement programmes have been initiated on teak in recent years. In India, and several other teak growing countries, most of the tree improvement works on teak have focused on selection of phenotypically superior trees (plus trees), establishment of seedling seed orchards, clonal seed orchards and seed production areas based exclusively on phenotypic traits like growth and vigor (MANDAL and RAMBABU, 2001). More recently, half sib progeny trials have been established in very few locations using seeds from selected superior trees. However, none of the above tree improvement programmes, either within or outside India have included assessment and genetic manipulation of specific wood traits like heartwood percentage and specific gravity though these are the most important economic traits in teak. Studies in several international provenance trials comparing the performance of different seed sources of teak have revealed considerable amount of differences between provenances in terms of growth and external stem quality (KEIDING et al., 1986; KJÆR et al., 1999) but these studies did not investigate internal wood quality traits. Further, it has not been possible to separate the large within provenance variation into genetic and environmental effects.

Though several studies have been carried out on wood parameters like specific gravity and fibre characteristics in teak using trees of different seed sources and provenances (RAO and DAVE, 1981; RAJPUT et al., 1982; VENUGOPAL and KRISHNAMURTHY, 1989; PANDEY et al., 1991; INDIRA and BHAT, 1997), only a handful of studies involved estimation of genetic parameters like heritability of growth traits viz., height, diameter and basal area (SWAIN et al., 1996; SHARMA et al., 2000). Selection and breeding for growth and wood traits for obtaining appreciable levels of genetic gains require adequate information on the heritability of these traits. Exhaustive studies have been made in temperate softwoods and hardwoods. In contrary, only a few studies have been carried out on tropical hardwood trees. Lack of genetic tests, especially progeny trials, has been the major bottleneck in genetic improvement of tropical hardwoods. Hence, information on genetic parameters, especially heritability estimates, is very much needed for developing strategies for genetic improvement for specific traits, particularly wood traits. Progeny trials offer valuable experimental material for investigations like estimation 
of heritability of wood traits. Heritability studies using progeny trial data in several temperate softwoods and few hardwoods have shown that most wood qualities as well as tree form and growth characteristics that affect wood are inherited strongly enough to obtain rapid gains through genetic improvement suggested, as reviewed in VAN BUIJTENEN and ZOBEL (1998). MANDAL and CHAWHAAN (2005) assessed the inheritance pattern of growth and wood traits in teak using data from a 21year-old progeny trial raised in Orissa state of India. Apart from the above study, there are no published estimates of heritability or genetic correlations for growth and wood traits in teak.

The aim of this study is to assess inheritance pattern of wood traits especially heartwood/sapwood percentage and specific gravity and analyze their interactions with other growth traits in a 27-year-old half-sib progeny trial of teak. Based on existing information and records available with state forest departments in India, the above teak progeny trial is most probably the oldest among the few existing in India or elsewhere. Since the trial has also reached almost $90 \%$ of its rotation period, information generated on inheritance pattern of the teak progenies could be valuable for developing strategies for improving quality of teak wood.

\section{Materials and Method}

\section{Half-sib progeny trial and collection of data}

The study was carried out in a progeny trial located at Lohara Research Centre Chandrapur, Maharashtra, India. The trial was established in 1978 by Maharashtra State Forest Department using open pollinated seeds collected from nine phenotypically superior trees (plus trees) of Allapalli region of Maharashtra. These plus trees have been selected based on their superior phenotypic traits (e.g., straight, round and tall stem free from insect and disease damage, less basal buttresses, few knots and few lateral branches). Each of the nine families was replicated in three blocks with 16 progeny trees in each. A completely randomized block design was used. For the present investigation, four trees were randomly selected from each family within each block (replicate) and measurements were taken on total tree height $(\mathrm{m})$, girth at $130 \mathrm{~cm}$ above ground $(\mathrm{cm})$ and bark thickness $(\mathrm{mm})$. Increment cores with $6 \mathrm{~mm}$ diameter were extracted from individual trees at $130 \mathrm{~cm}$ above the ground level. Proportions of heartwood and sapwood percentage were measured directly from the cores. In teak, heartwood and sapwood are clearly demarcated and easily identified without specific staining procedure. Wood specific gravity was estimated (OTEGBEYE and KELLISION, 1980) by the following ratio:

$$
\text { Specific gravity }=\frac{\text { Oven dry weight }}{\text { Green volume of sample }}
$$

Briefly, wood cores were soaked in distilled water (72 h) and green volume calculated at maximum saturation by water displacement method. Oven-dry weight of wood cores was directly measured at $0 \%$ moisture content after drying the wood cores at $100 \pm 2{ }^{\circ} \mathrm{C}$ for $48 \mathrm{~h}$.

\section{Data analysis}

Data on different growth and wood traits as recorded above were subjected to analysis of variance (Table 1) using general linear model procedures of SPSS 10 statistical package according to ZoBEL and TALBERT (1984), where $R=$ no. of replications, $F=$ no. of families, $T=$ no. of trees per plot, $\sigma^{2}{ }_{\mathrm{w}}=$ within plot error, $\mathrm{TR} \sigma_{\mathrm{F}}^{2}=$ variance due to families $\left(\sigma_{\mathrm{F}}^{2}=\sigma_{g}^{2}=\right.$ genetic variance among half-sib families) and $T \sigma_{R F}^{2}=$ replication vs. family interaction variance

Variance components due to families i.e. genetic variance $\left(\sigma_{\mathrm{F}}^{2}\right)$ and variance component due to family $\mathrm{x}$ replication interaction $\left(\sigma_{\mathrm{RF}}^{2}\right)$ were computed by equating the observed mean squares obtained by ANOVA with their expectations as given in Table 1 . Heritability $\left(h^{2}{ }_{(i)}\right.$ = individual tree heritability; $h^{2}(f)=$ family heritability), standard errors of heritability $\left(S E h^{2}{ }_{(i)}\right.$ and $\left.S E h_{(f)}^{2}\right)$, genetic gain (genetic advance; $G$ ), genetic gain as percentage of mean and general combining ability of the parents $(G C A)$ were calculated using formulae 1 to 7 (ZoBEL and TALBERT, 1984) as given below.

$$
\begin{aligned}
& h_{(i)}^{2}=\frac{4 \sigma_{\mathrm{F}}^{2}}{\sigma_{W}^{2}+\sigma_{\mathrm{RF}}^{2}+\sigma_{\mathrm{F}}^{2}} \\
& h_{(f)}^{2}=\frac{\sigma_{\mathrm{F}}^{2}}{\left(\sigma_{W}^{2} / T R\right)+\left(\sigma_{\mathrm{RF}}^{2} / \mathrm{T}\right)+\sigma_{\mathrm{F}}^{2}} \\
& S E h_{(i)}^{2}=\frac{\left(1-h^{2} / 4\right)\left[1+(T R-1) h^{2} / 4\right]}{[(T R / 2)(T R-1)(F-1)]^{1 / 2}} \\
& S E h_{(f)}^{2}=\frac{(1-t)(1+T R t)}{[(T R)(F-1)]^{1 / 2}}
\end{aligned}
$$

where $t=$ inter-class correlation equivalent of one forth of individual tree heritability

Table 1. - Format for analysis of variance of growth and wood traits of teak progenies. (Details are given in text).

\begin{tabular}{llll}
\hline Source of variation & $\begin{array}{l}\text { Degree of } \\
\text { freedom (df) }\end{array}$ & $\begin{array}{l}\text { Mean Squares } \\
(\mathrm{MS})\end{array}$ & $\begin{array}{l}\text { Expected Mean Squares } \\
(\mathrm{EMS})\end{array}$ \\
\hline Replication & $\mathrm{R}-1$ & $\mathrm{MSS}$ & $\sigma_{\mathrm{R}}^{2}+\mathrm{T} \sigma_{\mathrm{RF}}^{2}+\mathrm{TF} \sigma_{\mathrm{R}}^{2}$ \\
Family & $\mathrm{F}-1$ & $\mathrm{MSS}_{\mathrm{F}}$ & $\sigma_{\mathrm{W}}^{2}+\mathrm{T} \sigma_{\mathrm{RF}}^{2}+\mathrm{TR} \sigma_{\mathrm{F}}^{2}$ \\
Replication x family & $(\mathrm{R}-1)(\mathrm{F}-1)$ & $\mathrm{MSS}_{\mathrm{RF}}$ & $\sigma_{\mathrm{W}}^{2}+\mathrm{T} \sigma_{\mathrm{RF}}^{2}$ \\
Tree within plot & $\mathrm{RF}(\mathrm{T}-1)$ & $\mathrm{MSS}_{\mathrm{T}(\mathrm{RF})}$ & $\sigma_{\mathrm{W}}^{2}$ \\
(error) & & & \\
\hline
\end{tabular}




$$
G=i * h^{2} * \sigma \mathrm{P}
$$

where $G=$ genetic gain, $i=$ intensity of selection, $h^{2}=$ narrow sense heritability and $\sigma \mathrm{P}=$ phenotypic standard deviation

Genetic gain as percentage of mean $=\left(\frac{G}{\bar{X}}\right) * 100 \ldots$

Where $G$ = genetic gain and $\overline{\mathrm{X}}=$ general mean of the character/trait

$$
G C A_{a}=\overline{\mathrm{X}}_{a}-\overline{\mathrm{X}}
$$

where $G C A_{a}=$ general combining ability of parent $a$, $\overline{\mathrm{X}}_{a}=$ mean of progeny from all the crosses involving parent $a$ and $\overline{\mathrm{X}}=$ over all progeny mean of the test.

\section{Results and Discussion}

Averages including standard errors for growth and wood traits are given in table 2. Analysis of variance of wood traits (Table 3) showed highly significant variation for specific gravity, heartwood and sapwood percentage at family level. There was also non significant family vs. replication variation for these traits. Hence, there is hope for further selection of families for improvement of the above wood traits. Among the growth traits, there was significant variation for height and girth. However, these two growth traits were shown to have significant family vs. replication variation which showed that the above growth traits are significantly influenced by environmental conditions. Similar observation was made by MANDAL and CHAWHAAN (2005) in a 21-year-old progeny test where significant family vs. replication variation was observed for height, clear bole height and bark thickness which indicated significant genotype vs. environment interaction occurred for these traits.

Estimates of heritability at tree as well as family level are important when selection is based on individuals and families. In the present investigation, families and individual trees showed varying levels of heritability (Table 2). Among the growth traits, height showed high heritability (34.3\%) followed by girth (19.4\%). Similar heritability estimates for growth traits have been obtained by SHARMA et al. (2000) and MANDAL and CHAWHAAN (2005). Among the wood traits, heartwood and sapwood percentage showed maximum heritability both at family and individual tree level. Specific gravity exhibited heritability values of 29.1 and $41.8 \%$, at individual tree and family level, respectively. MANDAL and CHAWHAAN (2005) reported heritability values of 31.4 and $46.3 \%$ at individual tree and family level respectively for wood specific gravity at 21 years of age progeny trial. Similar estimates were obtained for Eucalyptus saligna (KING, 1980) and Populus (NEPVEU et al., 1978). In the present study, maximum heritability values were obtained for sapwood percentage $\left(h^{2}{ }_{(i)}=76.6 \%\right.$; $\left.h^{2}{ }_{(f)}=70.7 \%\right)$ and heartwood percentage $\left(h^{2}{ }_{(i)}=76.9 \%\right.$; $\left.h^{2}(f)=69.7 \%\right)$. In teak, higher percentage of heartwood is preferred in timber due to its high durability and resistance to pests and weathering. Selection of trees which have high percentage of heartwood is expected to increase wood production from short rotation plantation considerably (KJÆR, 2005). Height showed maximum genetic gain of $8.2 \%$ of mean followed by girth $(7.2 \%)$. Among the wood traits, sapwood percentage exhibited maximum genetic gain of $26.2 \%$ followed by heartwood percentage $(17.0 \%)$. The higher heritability for heartwood percentage and moderate heritability for specific gravity obtained in this study, supported by similar findings by other investigators (MANDAL and CHAWHAAN, 2005), indicates that considerable improvement is possible from a moderate selection progamme involving these traits in teak.

Family heritability was higher than single-tree heritability for specific gravity; single-tree heritability exceeded family heritability for heartwood percentage (Table 2). In both cases, it is concluded that mass selec-

Table 2. - Averages (n) including standard errors (S.E.) (108 trees), individual-tree narrow sense heritability $\left(h^{2}\left({ }_{i}\right)\right.$, family heritability $\left(h^{2}{ }_{(f)}\right)$ and genetic gain for growth and wood traits in teak progenies.

\begin{tabular}{lrrrc}
\hline \multicolumn{1}{c}{ Trait } & n (S.E.) & $h_{(i)}^{2}$ (S.E.) & $h_{(f)}^{2}$ (S.E.) & $\begin{array}{c}\text { Genetic gain } \\
\text { (\% of mean) }\end{array}$ \\
\hline Specific gravity & $0.66(0.01)$ & $29.05(0.04)$ & $41.78(0.25)$ & 3.13 \\
Height (m) & $13.20(0.58)$ & $34.28(0.04)$ & $34.06(0.27)$ & 8.20 \\
Girth (cm) & $52.79(2.49)$ & $19.42(0.02)$ & $31.43(0.22)$ & 7.19 \\
Heartwood (\%) & $56.01(2.26)$ & $76.94(0.08)$ & $69.65(0.39)$ & 17.02 \\
Sapwood (\%) & $27.52(1.54)$ & $76.55(0.08)$ & $70.68(0.38)$ & 26.15 \\
\hline
\end{tabular}

Table 3. - Analysis of variance for growth and wood traits in teak progenies (Only mean squares are provided).

\begin{tabular}{lrrrrrrr}
\hline \multicolumn{1}{c}{ Source } & d.f. & $\begin{array}{c}\text { Specific } \\
\text { gravity }\end{array}$ & Height & \multicolumn{1}{c}{ Girth } & $\begin{array}{r}\text { Bark } \\
\text { thickness }\end{array}$ & $\begin{array}{r}\text { Heartwood } \\
(\%)\end{array}$ & \multicolumn{1}{c}{ Sapwood } \\
\hline Replicate (r) & 2 & 0.0001 & 106.19 & 188.86 & 0.0162 & 417.423 & 277.918 \\
Family (f) & 8 & $0.0075^{* *}$ & $33.829^{* *}$ & $459.005^{*}$ & 0.0395 & $543.54^{* *}$ & $305.32^{* * *}$ \\
r x f & 16 & 0.0044 & $24.051^{* *}$ & $326.174^{*}$ & 0.0453 & 175.927 & 94.203 \\
Error & 81 & 0.0025 & 3.58 & 180.53 & 0.0291 & 112.861 & 67.721 \\
\hline
\end{tabular}

* Significant at $5 \%$ level; ** Significant at $1 \%$ level. 
Table 4. - Genotypic correlation coefficients for growth and wood traits in teak progenies.

\begin{tabular}{llllll}
\hline & Height & Girth & Bark thickness & $\begin{array}{l}\text { Heartwood } \\
(\%)\end{array}$ & $\begin{array}{l}\text { Sapwood } \\
(\%)\end{array}$ \\
\hline Specific gravity & $0.164 *$ & 0.118 & 0.079 & $0.282^{* *}$ & $-0.302 * *$ \\
Height & & $0.611 * * *$ & 0.059 & $0.533^{* *}$ & $-0.372^{* * *}$ \\
Girth & & & $0.183^{*}$ & $0.697 * *$ & $-0.500^{* * *}$ \\
Bark thickness & & & & -0.071 & -0.059 \\
Heartwood $(\%)$ & & & & & $-0.935^{* *}$ \\
\hline
\end{tabular}

* Significant at $5 \%$ level; ** Significant at $1 \%$ level.

Table 5. - General combining ability (GCA) for growth and wood traits.

\begin{tabular}{crrrrrr}
\hline Parent & $\begin{array}{c}\text { Specific } \\
\text { gravity }\end{array}$ & Height & Girth & $\begin{array}{c}\text { Bark } \\
\text { thickness }\end{array}$ & $\begin{array}{r}\text { Heartwood } \\
(\%)\end{array}$ & $\begin{array}{c}\text { Sapwood } \\
(\%)\end{array}$ \\
\hline MHALA3 & 0.02 & 0.18 & 1.31 & -0.018 & 0.75 & 0.96 \\
MHALA4 & 0.01 & 0.22 & 9.73 & -0.076 & 7.91 & -3.97 \\
MHALA5 & 0.04 & 1.93 & 1.48 & -0.068 & 5.17 & -3.44 \\
MHALA7 & -0.01 & 0.34 & 7.06 & -0.009 & -2.31 & 4.47 \\
MHALA10 & 0.00 & 1.14 & 2.69 & 0.087 & 5.25 & -4.84 \\
MHALA16 & 0.03 & 2.20 & -2.44 & -0.018 & 3.20 & -2.67 \\
MHALA17 & 0.01 & -1.86 & -7.19 & -0.018 & -1.55 & -2.58 \\
MHALA21 & -0.02 & -1.66 & -3.69 & 0.074 & -3.87 & 1.26 \\
MHALA35 & -0.04 & -2.51 & -8.90 & 0.045 & -14.56 & 10.78
\end{tabular}

tion is superior to family selection in the genetic manipulation of these traits as the variation among the trees for all the traits is large enough to compensate low single-tree heritability.

Specific gravity exhibited significant positive genotypic correlation with heartwood percentage (Table 4) suggesting that improvement in heartwood percentage would lead to a correlated improvement in specific gravity. Heartwood percentage showed significant positive correlation with growth traits viz., height and girth. This relationship indicates that height and girth can be used for prediction of heartwood production. Few other studies have also demonstrated that favorable relationship exists between growth and wood properties (VARGHESE et al., 2000). Hence, it may be possible to simultaneously select and breed teak for growth as well as wood traits.

General combining ability (GCA) signifies the average performance of the progeny of an individual when it is mated to a number of other individuals in the population (ZoBel and TAlBert, 1984). Parents having high GCA values for a particular trait are said to be good general combiners and such parents can be used for further advance-generation tree improvement programmes. In the present investigation none of the parents showed positive GCA values for all six traits simultaneously (Table 5). However, in timber species like teak, breeders prefer high growth rate of trees along with more heartwood production and high specific gravity whereas very thick bark and high sapwood percentage are not desirable. Perusal of Table 5 shows that four parents viz. MHALA3, MHALA4, MHALA5 and MHALA10 exhibited positive GCA values for height, girth, sapwood per- centage and specific gravity. Specifically, for specific gravity, MHALA5 showed maximum GCA value (0.04) followed by MHALA16 (0.03) and MHALA3 (0.02). With regard to heartwood percentage, MHALA4 showed maximum GCA value (7.91) followed by MHALA5 (5.17). Since positive GCA values of the parents indicate presence of additive genes, such parents can be expected to generate good segregants for different combination of traits (SWAIN et al., 1996). The good general combiners identified in the present study can be used for establishment of advanced generation seed orchards and breeding arboreta for improvement of teak for specific or combination of above traits.

\section{Conclusions}

The present investigation based on 27-year-old progeny trial showed moderate to high levels of heritability for important wood traits viz., heartwood percentage and specific gravity in teak. They indicate that significant genetic gains can be realized through a moderately intensive selection programme. Based on heritability estimates in this study, it is concluded that mass selection is superior to family selection in the genetic manipulation of these traits. Wood specific gravity, being an important wood trait in teak, also showed positive genetic correlation with other growth and wood traits. Hence, parents possessing good general combining ability for wood and growth traits could also be identified.

\section{Acknowledgement}

We are thankful to State Forest Department of Maharashtra, India, for their help in the above study. 


\section{References}

EARHART, J. (1999): An investor's perspective, pp. 10-14. In: Capital Markets and sustainable forestry: opportunities for investment, MacArthur Foundation, USA.

INDIRA, E. P. and K. M. BHAT (1997): Variability and heritability of wood density in teak (Tectona grandis L.f.). J. Trop. For. 13: 1-5.

Iтто (1998): Annual Review. International Tropical Timber Organization, Japan.

KeIding, H., H. WellendorF and E. B. LAURIDSEN (1986): Evaluation of an International series of Teak Provenance trials. Danida Forest Seed Centre. Humlebaek, Denmark.

KING, J. P. (1980): Variation in specific gravity in three years old coppice clones of Eucalyptus saligna growing in Hawaii. Aust. For. Res. 10: 295-299.

KJÆR, E. D., S. KaJORNSRICHON and E. B. LAURIDSEN (1999): Heart wood, calcium and silica content in five provenances of teak (Tectona grandis L.). Silvae Genet. 48: $1-3$.

KJÆR, E. D. (2005): Genetic aspects of quality teakwood plantations, pp. 311-320. In: Quality timber products of teak from sustainable forest management, edited by K. M. BHAT, K. K. N. NAir, K. V. Bhat, E. M. Muralitharan and J. K. Sharma, Kerala Forest Research Institute, Peechi and ITTO, Japan..

Mandal, A. K. and N. RAmbabU (2001): Quantitative genetic aspects of teak improvement, pp. 134-145. In: Genetics and Silviculture of Teak, edited by A. K. MANDAL and S. A. ANSARI, International Book Distributors, Dehra Dun.

MANDAL, A. K. and P. H. ChaWHAAN (2005): Investigations on inheritance of growth and wood properties and their interrelationships in teak, pp. 506-510. In: Quality timber products of teak from sustainable forest management, edited by K. M. BHAT, K. K. N. NAIR, K. V. BHAT, E. M. Muralitharan and J. K. Sharma, Kerala Forest Research Institute, Peechi and ITTO, Japan.
Nepveu, G., R. Keller and E. Tessier du Cros (1978): Selection juveline pur la qualite du bois chez certains peuplier noirs. Ann. Sci. For. 35: 69-72.

OtegBeye, G. O. and R. C. Kellison (1980): Genetics of wood and bark characteristics of Eucalyptus viminalis. Silvae Genet. 29: 27-31.

Pandey, C. N., H. C. KanoJi and Maniram (1991): Trials on bending of vapour phase ammonia plasticized wood. J. Timber Dev. Assn. 37: 4.

PAndey, D. and C. Brown (2000): Teak - a global review. Unasylva 51: 3-13.

RajPut, S. S., A. A. Gulati and V. K. Gupta (1982): On the suitability of timbers for railway sleeper. Indian Railway Bull. 39: 224-225.

RAO, K. S. and Y. S. DAVE (1981): Seasonal variation in the cambial anatomy of teak. Nordic J. Bot. 1: 535-542.

SHARMA, R., D. SwAIN and A. K. MANDAL (2000): Estimates of genetic parameters from an open pollinated genetic test of teak. J. Trop. For. Sci. 12: 44-48.

Swain, D., S. C. Mohanty, R. Sharma, A. K. Mandal and B. N. Gupta (1996): Preliminary analysis of quantitative characters in teak. Proc. INSA B 62: 169-172.

van BuiJtenen, J. P. and B. J. Zobel (1998): Genetics and breeding of wood, pp. 112-142. In: Forest Genetics and Tree Breeding, edited by A. K. MANDAL and G. L. Gibson, CBS Publishers \& Distributors, New Delhi.

Varghese, M., A. Nicodemus, A. P. K. Ramteke, G. Anbazhagi, S. S. R. Bennet and K. Subramanian (2000): Variation in growth and wood traits among nine populations of teak in Peninsular India. Silvae Genet. 49: 201-205.

Venugopal, N. and K. V. KRIShNAMURThy (1989): Organization of vascular cambium during different seasons in some tropical timber trees. Nordic J. Bot. 8: 631-635.

Zobel, B. J. and J. TAlBert (1984): Applied Forest Tree Improvement. Wiley, New York. 